\title{
Identity Dilemmas: Nation, Religion and Race Among the Portuguese Jews from Holland to Colonial Brazil
}

\author{
Ronaldo Vainfas \\ Department of History, State University of Rio de Janeiro, São Gonçalo, Rio de Janeiro, Brazil \\ Email address: \\ rvainfas@terra.com.br \\ To cite this article: \\ Ronaldo Vainfas. Identity Dilemmas: Nation, Religion and Race Among the Portuguese Jews from Holland to Colonial Brazil. History \\ Research. Vol. 9, No. 1, 2021, pp. 21-30. doi: 10.11648/j.history.20210901.13
}

Received: January 5, 2021; Accepted: January 22, 2021; Published: February 2, 2021

\begin{abstract}
This article discusses the identity dilemmas of the Sephardic community settled first in Amsterdam, after in the Colonial Brazil during the 17th century. It reviews the the classical historians dedicated to research on the Sephardic Diaspora in Early Modern History, like Arnold Wiznitzer, Daniel Swetschinsky, Jonathan Israel, Mirian Bodian and, mainly Yosef Kaplan, who proposed the concept of "new Jews" to designate the New Christians who returned to their ancestors Judaism in Amsterdam and Brazil. It is based on sources from the Kahal Kadosh Zur Israel, the Jewish congregation founded in the city of Recife under the Dutch rule during the 1630s, particularly the records and also the regulation of 1648. It analyses, mainly, several Holy office's charges against Jews who, during the Dutch rule in Brazil, converted themselves to Judaism, comiting the crime of apostasy from Catholicism. Many of them tried to scape from Pernambuco after the Dutch defeat, in 1654, but were catched by the Portuguese Inquisition during the 1650's and the 1660's. The focus of the discussion lies on the relationship between the concept of Men of the Nation (Gente da Nação in Portuguese) and religious and race identities adopted by this diasporic community. A community persecuted in for religious and racial reasons in the Iberian world, but that also owned his proper prejudices against some minorities, like the mulattos and the Ashkenazi Jews, whether in Holland, whether in Colonial Brazil.
\end{abstract}

Keywords: Sephardic, Men of the Nation, Judaism, Amsterdam, Dutch Brazil, Racial Prejudices, Conscience Dilemmas

\section{Introduction}

In his Dictionary of Concepts in History [15], Harry Ritter stated that the concept of Nation derives from the Latin verb nascere, indicating the place of birth or even the people bourn in certain place. It adds that this use of the word by the ancient Romans used to designate peoples distant from the Latin, strange people. In the seventeenth century, according to Ritter, the word Nation began to associate slowly, in various European languages, with the territorial and cultural dimensions where lived certain group, referring to a common ancestry to a certain group, as well as to shared written or oral traditions. Only throughout the seventeenth century did the concept of nation tend to associate itself with the political variable, bringing the territorial and cultural dimensions closer together, which resulted in the concepts of National State and Nationalism [15].

In the Portuguese case, Rafael Bluteau offered three meanings for the word Nation in his Portuguese and Latin
Vocabulary, published in 1728, followed literally by Antônio de Morais e Silva, in the Portuguese Language Dictionary, dated 1789. First, he defined nation as the people of a country or region with "self language and own laws and government own", exemplifying with the French, Spanish and Portuguese nations. Secondly, he recorded the variant Men of the Nation as a synonymous the Jewish descendants, the so called New Christians. Thirdly, he suggested that nation could mean "race, caste, specie." [3]. Such semantic possibilities of the Portuguese language suggest, in the first meaning, a concept of nation identified to the idea of nationality, political autonomy, territorial sovereignty; in the other meanings, the particular and discretionary sense of nation prevails, sometimes identified with race, especially in the case of the New Christians.

Bluteau wrote in the early decades of the eighteenth century and, perhaps for this reason, highlighted the "people of the nation" in his entry, for it was in the reign of d. John V that the persecution of the Portuguese New Christians by the 
Inquisition reached its peak. In this case, Bluteau recorded a nation meaning strongly marked by repudiation of otherness, rejection of Jewish origin or blood. It is not new to say that the statutes of purity or cleansing of blood in old Portugal, as well as in Spain, had long ago stigmatized the Jewish origin of converts, suspected of heresy or apostasy because of their ancestry. This means that although heresy in canon law was defined as an erroneous choice of conscience in the field of religion, New Christians were considered potentially heretics because they descended from Jews.

Here is a conceptual dilemma in the theological field: did heresy depend on erroneous choices in matters of faith based on the free will of baptized devotees or did they stem from the heretical blood of cultural or racial minorities? In inquisitorial practice, the focus was, in fact, on examining the choices of conscience assumed from certain Judaizing acts, but the ancestry of the defendants weighed heavily in the judgment of the inquisitors.

In any case, the institutional discrimination embedded in the nation's concept of people came from far away, and was not restricted to stigmatizing Jewish descendants. Portuguese cleansing statutes also marked the descendants of Moors, Africans, American Indians, as well as Mamluk and Mulatto. The discrimination of the statutes resided, a priori, in the religion of the ancestors, be it the unfaithful origin, the gentile and, above all, the mixture of races that perpetuated the blood impurity. Blood and ancestry blended, as criteria, to reserve certain positions or titles to the Old Christians of the Portuguese society of the Ancien Régime.

Maria Luiza Tucci Carneiro exposed, with details, institutional discrimination in Portuguese world in her book Preconceito racial no Brasil Colônia [7], while Albert Sicrofft did the same for the Hispanic world in a classic book, Los estatutos de limpieza de sangre [19]. But it is not the case to detail the here institutional dimension of discrimination. What matters first is the discriminatory use of the concept of Nation in the Portuguese world since the sixteenth century.

In the vast chronicle produced in Colonial Brazil, indigenous groups were classified in the sixteenth century as members of the groups Tupinambá, Tamoio, Caeté, Potiguara, Tabajara and many other nations among the Tupi language speakers. An effort to differentiate groups inscribed in a certain otherness, often defined generically as "Gentiles" or "Blacks of the land". Not to mention the differentiation between Tupi and Tapuias - the non Tupi speakers - a notion conceived by the Tupi themselves, majority settled on the coast, adopted by the colonizers since the beginning of the Portuguese colonization.

Inquisitorial documents from the sixteenth century also used the concept of nation to refer to Africans, generically called "blacks from Guinea," but sometimes individualized. Just one example: in a testimony recorded in Bahia in 1591, one man called Jeronimo de Barros identified as "black from Guinea" the African slaves Antonio de Guinea, Antonio Arda, Pedro, Lorenzo and Joane Ongico, Rodrigo and Cristovão Angola; on the other hand, by mentioning the indigenous slaves, he cited nominally Manuel from the Land and Francisco from the Land (meaning the Brazilian land) [22]. In this example, we perceive the presence of generic denominations to distinguish Africans and natives some from Guinea, some from the Land - without prejudice to an individuation effort. The origin of the Africans (Angola, Ongico) appears in this document as a kind of family name - which was not the case - neither in the case of the indigenous slaves Francisco and Manoel "from the Land".

This classification effort, sometimes of individuation, very present in the 16th century chronicles, took the particular concept of nation I referred, for meaning "the others" or different peoples. In the African case, ethnographic identification was arbitrary, as Mariza Soares demonstrated [20], as did indigenous classifications, as Regina Celestino de Almeida indicated [1]. In any case, they illustrate some uses of the word nation to designate the racial and cultural otherness of the peoples enslaved.

Returning to the Portuguese inquisitorial documents, when they outlined to register some synonymy between the concept of nation and that of nationality, they privileged the difference in detriment of some shared identity. Several sources of the sixteenth century Holy Office Visitation record individuals such as "French of Nation", "English of Nation", "Castilian of Nation", never as "Portuguese of Nation", although Bluteau included "Portuguese Nation", among the examples of his Vocabulary. In the case of the Portuguese, it used to be recorded, in the roles of the Holy Office, where the individual was from, which city, region or bishoprics of the kingdom. The idea of homeland used by the Portuguese was thought in a regional way. This holds true, to some extent, for other European kingdoms. The word country usually meant some region or village. For the Portuguese, the members of any other nation, like Indigenous, Africans or Europeans from the several Realms or Republics, were included among the foreigners.

\section{Men of the Nation: Persecutions and Diasporas}

The best evidence of the discriminatory use of the word nation in Portuguese vocabulary appears, however, in the definition of New Christians. The full expression then used was Men of the Hebrew Nation - alluding to the Sephardic of the Lusitanian kingdom or to the overseas colonies. Certainly, as I already said, the term was also used to refer to other groups, such as "from the Moor Nation", "from the African Nation", "from Indigenous Nation". But it was not long before the use of the expression Men of the Nation, without a nominal predicate, began to designate mainly the Jewish origin of the so-called Nation. Therefore, when someone would say Men of the Nation, everyone understood that they were the New Christians from Jewish origin and, therefore, people of impure blood and able to commit the Mosaic heresy, if not to apostasy. 
In his valuable glossary on the Inquisitorial vocabulary, Elias Lipiner recorded some variants of the expression Men of the Nation, such as the New People, meaning a new race with heretical blood, in contrast to Old Christians, endowed with pure blood. A formula in which the new indicated the "infected blood" of the New Christian minority; and clean, by contrast, alluded to the purity of blood of the Old Christians [12]. This institutional and moral degradation of the Men of the Nation marked the Portuguese history until the eighteenth century.

For beyond the Portuguese world, however, there was an inflection, not to say inversion, in the use of this term. This occurred amid the first Sephardic diaspora, concentrated between the mid-fifteenth century and the middle of the following. A diaspora corresponding to the period of persecution on the Iberian Peninsula and the establishment of the Inquisition. In Spain by the Catholic Kings, Fernando of Aragon and Isabel of Castile, in 1480 [14]; in Portugal by the conversion of the Jews by d. Manuel, in 1497, and by the installation of the Holy Office in 1536, already in the reign of d. João III [10].

There are several studies on the Sephardic in the Mediterranean that, when rebuilt their communities, began to use the expression Men of the Nation in their favor, in a positive sense, either as a basis for their own identification and/or for the relations with the powers that admitted them in each realm or city.

Fleeing the Inquisition or seeking lands where Judaism was tolerated, thousands of Sephardic left the peninsula alone or in family, settling in various parts of the Mediterranean which, as Braudel demonstrated, was retain its traditional position as a axis of trade and financial of the Old World, throughout the sixteenth century, despite the oceanic European expansion. Several Sephardic communities were erected in Italian cities such as Venice, Livorno or Ferrara, supported by the local nobility. Even Rome was a refuge of Sephardic, generally under the pope's support. The same thing happened in the Islamic world of the Mediterranean, such in Morocco, with the consent of Fez's xarife, or in several cities of the Ottoman Empire, like Smyrna in Greece, for instance, with the approval of the sultans.

This first diaspora also included migrations to Africa, Asia and Brazil, to a lesser extent, but no Jewish congregations were erected in those parts, cause the Judaism has been banned since 1496 in the Portuguese world. The most common, in general, was the practice of clandestine and domestic Judaism, designated at that time as "to make esnoga" - the equivalent of Crypto-Judaism. In general, this Crypto-Judaism meant to preserve the Shabbat, the Holy Saturday; to observe the funerary rites; to prepare the food as fixed by the oral law (Halacha, in Hebrew); to avoid eating forbidden foods by the Levitical law, as pork, rabbit meat, "fish without scale" (crustaceans) and so on. Only the elders of the first generation of converts still maintained synagogue traditions, certainly fragmented, which tended to disappear over the years.

\section{Men of the Nation: Identity Recovered in the Exile}

Persecuted in the Iberian world, Sephardism was reborn and multiplied in the Mediterranean, because there were many places called "lands of freedom" by the Sephardic. there. In several cases there was a transplant of Sephardic tradition to these parts, carried out by Old Jews, that is, traditional Jews who had refused to convert themselves to Catholicism or those who, although converted, remained linked to their traditional faith. There are several studies on the Sephardic in the Mediterranean that, when rebuilt their communities, began to use the expression Men of the Nation in their favor, in a positive sense, either as a basis for their own identification and/or for the relations with the powers that admitted them in each realm or city [11].

There was a true semantic rematch. While it is true that the nation thus defined remained particular, implying a selfawareness of its own singularity in the face of the allencompassing society, it also came to mean a certain aggregative and joined identity, grounded in the Jewish faith and in the Iberian origin of its members.

This semantic rematch lasted into the second Sephardic diaspora, started between the late sixteenth and early seventeenth centuries. Migration would now directed to the Netherlands, with frequent stopover in French cities, until reaching Antwerp, in nowadays Belgium, then the Netherlands, especially Amsterdam, extending through Hamburg in northern Germany. On this route, in a increasing rhythm, families of Portuguese New Christians or part of them were settled since South France to North Germany, but mainly in the Low Countries [17]. The Sephardic Diaspora has always been characterized by family fragmentation, whether from the nuclear family or from a extended family with several relatives linked. In this Sephardic the Diaspora, in the first or i the second one, it was very common for the couple to migrate without their children; the husband without the wife, the couple with some children, some not, who were left under caring by uncles or grandparents.

This familiar fragmentation was therefore often painful, but was also promising, cause paved the way for of material prosperity. For it was through this fragmentation on a European, and soon planetary scale, that the Sephardic emerged as protagonists of a world market since the sixteenth century, as Braudel stressed in his book on the sixteenth century [6]. Mediterranean. I refer, therefore, not only to the New Christians who returned to Judaism in lands of freedom (reneging Catholicism), but also to the those who, living in "land of idolatry," as they used to call the Catholic countries, limited themselves to a few of Jewish practices as wellmitigated as secret.

In the case of the second European diaspora, the reorientation was due to the growing affirmation of the North Sea as a new space for European business, already well connected to other continents, trough the Atlantic and the Indic ocean. The Sephardic were everywhere. As in the case of the Mediterranean diaspora, in the places one were 
admitted, they were then benefited to Dutch religious tolerance. Some came in runaway from the Inquisition, others would eager to retake their grandparents' beliefs and rites. Amsterdam came to be designated by them as North Jerusalem.

\section{Identity Dillemmas Among the New Jews}

But this second diaspora offers complicators of great historical and anthropological interest. Several authors have researched the subject, including historians, linguists, ethnologists, literature scholars.

For instance Jonathan Israel who, among several works, studied in his book Diasporas within a Diaspora, already mentioned, several Sephardic migrations between the sixteenth and seventeenth centuries, in a comparative perspective, included the Jewish's or the New Christians' settlement in Holland, in France, England, North Africa, the Ottoman Empire, the Caribbean Islands and Brazil. Miriam Bodian, in her book Hebrews of the Portuguese Nation, stressed the resistance of the Sephardic culture in the Amsterdam's exile, as well examined the conflicts between the Jewish authorities of the rigorous Mahamad (the Jewish Council), and some brilliant dissidents [4]. Baruch Spinoza, for instance, considered a great philosopher two centuries later, a thinker who questioned the Divine Providence and sustained the primacy of the free thought, building, trough that, an original philosophy, maybe the basis of the first laic philosopher system emerging in the Early Modern History. Daniel Swetschinski, in his Reluctant Cosmopolitans, highlighted the Sephardic congregation genesis, perceived as a religious, ethnical and economic group at the same time. As others historians, although based upon some unknown sources until his research, many of them with statistic data, he stressed the merchant and financial role of Amsterdam's Portuguese Jews. He shows us that many of them acted as brokers or were intermediates in oversea routes, and also in regional or local trade, distributing special commodities from India or from the Americas to Holland with high profits. The author proves, with strong data, the great importance of the Jewish networks allover the world for the Dutch prosperity in the first mid of the seventeenth century [21]. Harm den Boer, by his turn, changed the focus to the literary culture of the Amsterdam's Sephardic. It is a classic study on the Poetry, on the theological books or historical and political works written by the Jews. Besides, Harm den Boer researched the Jews' press in Amsterdam, as the David Tartas' one and, mainly, that directed by Manuel Dias Soeiro, more known as Menasseh Ben Israel, the major rabbi from Portuguese origin in Dutch seventeenth century [5].

The bibliography dedicated to the Sephardic in Holland is large and highly qualified in many fields of the History. Nevertheless, I would like to highlight Yosef Kaplan, an Argentinian historian, Professor at the Jerusalem University, mainly because he proposed a new concept for the study this phase of the Sephardic diaspora in North Europe. He build the concept of New Jew, a concept symmetrical to the notion of New Christian, just to designate the Portuguese Jews settled in the Netherlands during the 1600's (KAPLAN, 1966). The same Jews, by the way, who migrated to Brazil in the "time of the Flemish", a subject that I studied in a recent book [23], after others great works like the classic works Gente da Nação (MELLO, 1996) and The Jews in Colonial Brazil [24].

In his book Judíos Nuevos en Amsterdam, Kaplan problematizes the institutional, religious, and identity dilemmas of New Christians engaged in the reconstruction of Judaism in the Netherlands. Kaplan dismisses at the outset any illusion of Jewish essentialism, instead adopting a historical-cultural approach, and suggests that the New Christians who migrated to Amsterdam, even though CryptoJews in the Iberian world, knew little or nothing of traditional Judaism. Away from forced conversion for over a century, the majority of them had a Christian background. Some had studied at Iberian universities or entered religious orders without professing full vows. The few who knew anything about traditional Judaism had drunk from secondary, Catholic, and anti-Jewish sources, such as polemist literature against the errors of the "old law of Moses."

The overwhelming majority of Sephardic immigrants in this immigration group did not read Hebrew and were unaware of the books of the Jewish religion. Even the Torah the five books of the Pentateuch - was inaccessible to most. It is worth remembering that in the Catholic world, the Bible was a book authorized only in Latin for the for clerics, except in special authorizations, and the Church prohibited its translation into vernacular languages. Most Christians were unaware of the Bible. The first translation of the Bible into Castilian language just appeared in 1553 in the city of Ferrara, composed of New Christians converted to Judaism and restricted to the Old Testament. A Bible made up of Jews and exclusively for Jews [9].

Faced with so many limitations, Kaplan says that for most (re) converts in Amsterdam, "the first Jewish community they knew was the one they had created." Therefore, it would be impossible to think of the newly converted Portuguese or Spanish Jew in Amsterdam as an Old Jew, a traditional Jew, like a Jew of Fez, Smyrna, or Venice, men who transferred the Sephardic tradition to the Mediterranean since the fifteenth century. In these case, I stress, that were Old Jews. The New Christians that reached Amsterdam and converted themselves into Judaism during the seventeenth century were so different. Here we can apply the concept of a New Jew emerging in the second diaspora: a Jew in formation, a Jew in search of a religious and cultural identity unknown. Kaplan claims, with some exaggeration, that most of the New Jews from Amsterdam were "Jews without Judaism." [15]

1 - The Dutch conquered the sugar Captaincies of Brazil, excepted Bahia, in 1630, suppported by the Dutch West indian Company, and ruled the region until 1654. Along the 1630', they authorized the imigration of the Portuguese Jews (New Jews) from Holland to Pernambuco, th main sugar Captaincy of the Brazilian Northeast and centre of the Dutch power in the colony. 
Nevertheless, is certain is that the building of the Sephardic community in the Netherlands has depended on hiring Mediterranean rabbis, Old Jews, as I said. The assumption of a strong Judaism, based upon in the spirit and progeny of every New Christian, is not possible to sustain, historically, although it was almost a motto of the community. In the official speech of the exiles, this was, by the way, very prominent: all New Christians were considered to be "sons of Abraham" even if they ignored the law of Judaism. In practice, however, the story was different. Many of the first generation of Portuguese Jews in the Netherlands suffered tremendous identity crises - not knowing whether they were apostates of Catholicism or reconverted Jews.

Portuguese Jews from the Netherlands, adopted the expression Men of the Nation as their identity mark, as has did their Mediterranean predecessors; and here more firmly, sometimes with excessive rigor, considering the insecurity of the majority on to who was what or who was who; or, as affirmed Stuart Schwartz, they had serious doubts about in which law they could reach spiritual salvation, if the the Law of Christ or the Law of Moses [18]. The concept of Men of the Nation, in its aggregative aspect, could mitigate dilemmas and tensions, without resolving them, however, in the short term.

Kaplan offers valuable evidence of these dilemmas by examining the statutes of the Holy Company of Endowing Orphans and Poor Maidens, or in Portuguese, Santa Companhia de Dotar Órfãs e Donzelas pobres (1615), an institution dedicated to providing dowries for aspiring young Jewish women poor in general, trough a marriage [15]. After all, the leaders of the community - mainly the members of the Jewish council (Mahamad) - were well aware that the reconstruction of Judaism in "lands of liberty" could not depend solely on escape, but on the constitution of genuinely Jewish families in the medium term. Purely Jewish families. In the document in focus, the women candidates for dowries would be must necessarily be of Portuguese or Spanish origin, although they could reside in several parts: the Portuguese or Spanish world and its colonies, certainly, but also in a vast territory, since Saint-Jean-de-Liz, on the Spanish border with southern France, to Dantzig (Gdańsk, in Polish), located in Pomerania, East Prussian border with Poland (where there were also Sephardic), as well as in France, Flanders, later in England and some regions of future Germany. A large spatiality, a scattered territoriality was admitted for the recruitment, but the origin of the individuals should to be necessarily Iberian.

In this sense, the Amsterdam community ignored the Portuguese-Castilians rivalries, resulting from the Iberian Union, since 1580, or from the Portuguese Restoration, after 1640. Their conversas families had had mixed a long time ago. In Western Europe, the identification of the "young women" of the Nation followed the Sephardic migration route to Amsterdam, including stopovers in southern France, sometimes long seasons, blooming in the Netherlands or Hamburg. The inclusion of France and Flanders in the recruitment areas is explained by the fact that they are both transit regions on the route to Amsterdam - Antwerp, in Flandres, located in now Belgium, was in fact the pioneering focus of the Sephardic presence in northern Europe, since the XVIth century. In Flanders, Judaism was banned with the victory of Philip II in the late sixteenth century. In France, in turn, the prohibition occurred that same year 1615, by force of decree of Maria de Medici [13]. In both regions, however, Crypto-Judaism was strong and in France it was almost wide open. In the eastern European recruiting band, as I said, the statutes included Germania and Dantzig because of the presence of Sephardic merchants in Hamburg, who operated east of the Netherlands, including the Baltic.

\section{The Sephardic Exclusivism in Amsterdam and Dutch Brazil}

Sephardic exclusivism is confirmed by the statute's clause defining Dotar's institution "companions," that is, those who regularly gave donations to the association. Were admitted in the Company, in addition to the Jews residing in Amsterdam, the residents settled in other Kingdoms, provided there was certain news that they "believed in the unity of the Lord of the world" (and not in the Holy Trinity) and knew Jewish law - whether or not they were circumcised. The Company even admitted New Christians to his ranks, in the case of men, considering that they were Jews in their own hearts, though Christians in the exterior (potential Jews who lived "outside Judaism), always expecting them to become assumed Jews.

The difference of the Dotar's treatment of men and women is remarkable. In both cases, New Christians, whether men or women were included in the concept of Men of the Nation: the women as an object of recruitment for marriage; the men to offer financial resources. However, if in the case of men, it was admitted they could lived in Iberian countries, pretending to be Christians, the same did not happen with women. Spain and Portugal were excluded from the recruitment of orphans and maidens. Commenting on this exclusion, the historian Daniel Swetschinski put forward the hypothesis that Dotar's administrators did not trust in the New Christian women who lived in the Iberian Peninsula, considering that the Crypto-Judaism there was clandestine and weak. We must question here: why this would also not compromise the inclusion of New Christian men that used to live in the Iberian world? Why would the Crypto-Judaism of young Christian women would be more weak than that of men? It surprises the women's discrimination by the Dotar's statute, considering that were the women the principal protagonists in keeping the Sephardic traditions at home, since the sixteenth (ASSIS, 2012) to the eighteenth century [8].

However, let us avoid sexist interpretations. The Dotar's directors preferred select women who were already in transit to the Judaism, poor women who had already abandoned the "land of idolatry", living in regions where Crypto-Judaism was tolerated. These men did not want to take the risk of endowing women who, for some reason, were reluctant in 
leaving the Catholic world. In the case of men, flexibility had been due to the fact that many merchants and bankers of the Nation were New Christians settled in Portugal, Spain and Iberian colonial areas. Intense mobility, typical of wholesale traders in global scale. Dotar's directors preferred to think that the males of the Nation were Jews stronger than the women in the Jewish faith, besides of what they were the great investors for the formation of new Jewish families in Holland.

Dotar's statute also established a special relationship between the future wives from he Nation and the members of the association. Although gifted women were chosen by periodic sweepstakes, a hierarchy of priorities was established from two categories: kin women and particular women. The kin women had to have blood ties to the third degree with the future husbands, except, obviously, the first degree relationship. The particular women, who hardly got dowries, were exempted to have kinship ties with the fiancé. This was a policy clearly aimed at regrouping, as far as possible, relatives fragmented by the Sephardic diaspora.

Therefore, by examining the ideal marriage model conceived by the Amsterdam Sephardic community, we can sketch a typical member of the Men of the Nation. The typical "male of the nation" should be necessarily Iberian, included the Spanish of them, considered the various unions between Jews and converts of Portugal and Spain, as well as the strength of Judeo-Castilian culture in the Sephardic Diaspora. The single "man of the nation" should also preferably be a great merchant, or at least someone integrated into the commercial networks in the world. He could even be a fake Catholic, if living in some "idolatry land" as long as he had financial resources. The "woman of the nation", in turn, should be, besides Spanish or Portuguese, a potential Jew, living on the borders or on her way to the so called "North Jerusalem." If she lived in Portugal, she was no so good for be a Portuguese Jew's wife, or at least she would not have a marriage funded by the Amsterdam association. In addition to being Jewish at heart, she had to be the daughter, sister, grand daughter, or cousin of a Dotar member.

The great Sephardic investors thought they deserved privileges in the endowment process, favoring their relatives. This policy aimed to reinforce or remake the more riche's families among the Men of the Nation. Anyway, Dotar's statutes give clear proof that the endogamy model, inside the community, or even the consanguinity, inside some family in particular, was the ideal model for the Sephardic marriage. In fact, several sources on the Sephardic daily life, included the inquisitorial processes against those who were imprisoned later, suggest that most of the New Jews from Amsterdam, in the early decades of the seventeenth century, spoke Portuguese at home and prayed in Spanish in the synagogue. Several New Jews later caught by the Portuguese Holy Office, were obliged to write the Jewish prayers the used to say during the Jewish's cult. At this initial phase, it is no doubt that they used to pray in Castilian language, perhaps in ladino language. Why? Because the small catechism books used were based upon the Ferrara's Bible, the first Bible in an
Iberian language, as I said at the beginning of this Chapter, written mainly in Castilian. For the great majority of the New Jews completely the Hebrew language was completely unknowable, as I already noted.

Therefore, perhaps it is not an exaggeration to say the Portuguese New Jews of Holland were more Iberian than Jews, first of all because they have marginalized Ashkenazim Jews who settled in Amsterdam from the 1630s. I must stress, here, the strong exclusions inherent in the concept of Nation used by the Portuguese or Hispano-Portuguese Jews in their diaspora, first of all against the so called Polacos and Tudescos ${ }^{2}$. Escaped from the Thirty Years' War, Polish and German Jews actually were different a lot from Sephardic in that time:

1) the Sephardic had a heritage cultural Christian and Iberian heritage culture, and part of them acted in the largescale commerce, as leaders international merchant networks; the Ashkenazim, for their part, were in general poor, but endowed with a Jewish education, taught in community schools of rural villages;

2) the Sephardic spoke Portuguese, Spanish or Ladino and the most intellectualized also read and spoke French, Italian, Greek and Latin, while the Ashkenazim spoke only Yiddish and the language or dialect of their born region, especially German and Polish, although they knew how to pray in Hebrew;

3) the Sephardic, as New Jews, were in the process of conversion into a Judaism almost unknew, except in a fragmentary and superficial manner, while the Ashkenazim were traditional Jews who, on their refuge in Amsterdam, moved away from the Jewish communities of the CentralEastern Europe.

It is worth repeating a formula: the Sephardic of Amsterdam were New Jews; the Ashkenazim were very Old Jews, they had been always Jewish and never considered the possibility to converting to Christianity.

The stance taken by the Sephardic authorities in the face of the growing presence of German and Polish Jews in Amsterdam was apparently that to help them, at least at the beginning of the contacts. Newcomers were allowed to attend synagogues and bury their dead in the Ouderkerk cemetery, Bet Haim. After all, strange as they were in the eyes of the Portuguese and Spanish, the Ashkenazim were Jews actually. The Ashkenazim also received financial support for funerals, medical treatment and even money if they were to emigrate (not to stay in Amsterdam). But it is a fact that the Sephardic wanted to keep their distance from the Jews whom they called Tudescos (Germans) or Polacos (Poles), with strong pejorative tone. The continuous influx of Jewish migration from the east complicated this picture. In addition to incompatibilities between the two groups of Jews, the begging in the streets by the poor eastern Jews in the or their growing insertion in the retail trade (in spite of the JewishDutch agreements that forbidden it) irritated the Sephardic.

2 - Polacos was the word that the Portuguese used to designate the Poles Jews. In the case of German Jews they used the word Tudescos. 
They feared losing the protection enjoyed in the Netherlands and did not want to be confused with those "poor and ignorant Jews", as the Men od the Nation used to call them.

In fact, many people among the Ashkenazim of Amsterdam became workers or even servants of the richest Sephardic. They carried goods boxes, cleaned the houses and synagogues, served as domestic servants. They could attend the synagogue, but separately, and had no rights in the congregations. When come out the unification of congregations, with the foundation of Talmud Torah in $1639^{3}$, the third article of their statutes was almost a manifesto against the Ashkenazim. The article established that the community newcreated was intended only for "Jews of the Portuguese and Spanish Nation", meaning not just those who lived in Amsterdam already but also those who expected to live there.

The growing up of exclusionary measures was progressive. That same year, the Men of the Nation were prohibited from buying meat sold by the Tudescos and Polacos, accused of not observing the traditional rites in the slaughter of animals. An Ashkenazi butcher was accused in 1640 of not wiping his knife between one and the other sticking chicken. The meat sold by the Tudescos was considered unclean - but in fact it was also cheaper than that sold by the Sephardic butchers. In 1642, the Ashkenazim were forbidden to bury their relatives in the Bet Haim cemetery, receiving, in return, for charity, 300 guilders to build their own cemetery. It looks like that the Sephardic did not want, not at all, the company of the Ashkenazim, whether alive whether dead. In 1644, the Sephardic Council prohibited the circumcision of Ashkenazim newborn in the Talmud Torah synagogue. Little after, the Council condemned the marriages between Ashkenazim and Sephardic, as if such unions contaminated the blood's purity of the Iberian Jews.

Actually, it is possible to see in this attitude a replica of the principles of "blood cleansing" had prevailing in the Iberian world. In the Iberian Peninsula, among the Catholics, the bearers of "infected blood" were the descendants of the Sephardic Jews; in Holland, among the Sephardic Jews, the "infected blood" seemed to be that of the Germans and Poles. The ideal marriage for the New Jews, as I already said, should be that celebrated between Sephardic men and women. The parents of Sephardic girls would rather marry them with New Christians (as long as they convert, of course) than with German or Polish Jews. The parents of the Sephardic young women preferred marry them with New Christian men (as long as they converted themselves to Judaism, of course) than with German or Polish Jews.

If the situation of Ashkenazim men was already difficult,

\footnotetext{
3 - No início do século XVII, foram fundadas sucessivamente, três congregações judaicas em Amsterdã: Beth Iacob (House of Jacob) em 1603; Neveh Shalom (Peace home), em 1608; Beth Israel (House of Israel), em 1608. The relationship between these three congregations was peaceful until the $1620 \mathrm{~s}$, despite some disputes between the leaders for financial reasons, but the centrifugal tendencies were offset by several cooperative initiatives. In the $1630 \mathrm{~s}$, rivalries surfaced, but in 1639 resulted in the unification of the three congregations in the Kahal Kadosh Talmud Torah (Sacred Congregation for the Study of the Torah).
}

that of women was worse. The greatest restrictions were focused on the union between Sephardic men and Ashkenazi women. Marriages of Sephardic women with Ashkenazi men, although rare in the seventeenth century, were more tolerated by Men of the Nation. In the daily life of the Amsterdam Portuguese Jews, the hierarchy was confirmed. German or Polish women could only sit in the synagogue galleries if Iberian women had been accommodated. And if any Sephardic woman was late for worship, the Germans and Polish women had to give way their place.

The leaders of the Talmud Torah, however, had guilt of conscience over their treatment of Yiddish-speaking Jews. They created the Avotad Hesed (Work of Grace) in 1642, an association charged with financially assisting the Ashkenazi who wanted to leave Amsterdam. Many accepted the offer and were "dispatched" back to central and eastern Europe. Most of them had preferred to stay. The Ashkenazi community would only grow throughout the eighteenth century, by its own strength and aided a little by the Talmud Torah, despite all this.

The exclusion of German and Polish Jews was not the only discrimination adopted by the Talmud Torah. In the same marginal situation were the blacks and especially the mulattos, children of young Christians with black slave women who accompanied their parents or only their father to Amsterdam. They were free - sometimes liberated slaves who were willing to follow the Jewish religion by paternal decision. Some arrived already circumcised. But the Mahamad tended to quell the mulatto expectation, alleging the "Gentile motherhood", besides his skin's color. Eventually, the fathers more riches had proffer any donation to the Jewish Council, aiming to lift the obstruction against their mulattos suns. Eventually, the New Jews more riches used to proffer some donation to the Jewish Council, aiming to lift the obstruction against their sons considered mulattos. But their condition inside the Sephardic community was, anyway, very hard.

Mulattoes were admitted to the congregation only as second-rat Jews, prevented from reading the Sefer Torah, and deprived of rights. There is no record of mulattoes circumcisions in the sources, which suggests that they were frequently prevented from be converted. Nor is there a record of marriages involving women or men mulattoes in Amsterdam Jewish community during the seventeenth century. Mulattoes could only be buried at Bet Haim in private ground, separate from whites, such as the Ashkenazim. In general, the New Christian mulattoes were employed in hard services, such as the Germans and Polish: cleansing the synagogue, carrying boxes, serving at the home of wealthy Jews. The mulattoes who sought Judaism in Amsterdam did not get to be enslaved; but they found in Holland a servile condition and a racist discrimination.

The depreciate of the mulattoes, besides the allegation that they descendant of gentile mothers, demonstrated a strong heritage of slave values combined with the Iberian ideals of blood purity. The Sephardic Council had often found itself in difficult situation to admit half New Christian, sons of 
Catholic mothers and father New Christian. Would not the impediment of "Gentile motherhood" (Goim in Hebrew) also apply in these situations? The resolution of this kind of stalemate ended in casuistic, as it was difficult for the Mahamad to veto the entry of a rich Jew's son, whatever his color or origin.

Like in Amsterdam, the Jews of Pernambuco were exclusivists, and admitted only those of Iberian origin [23].

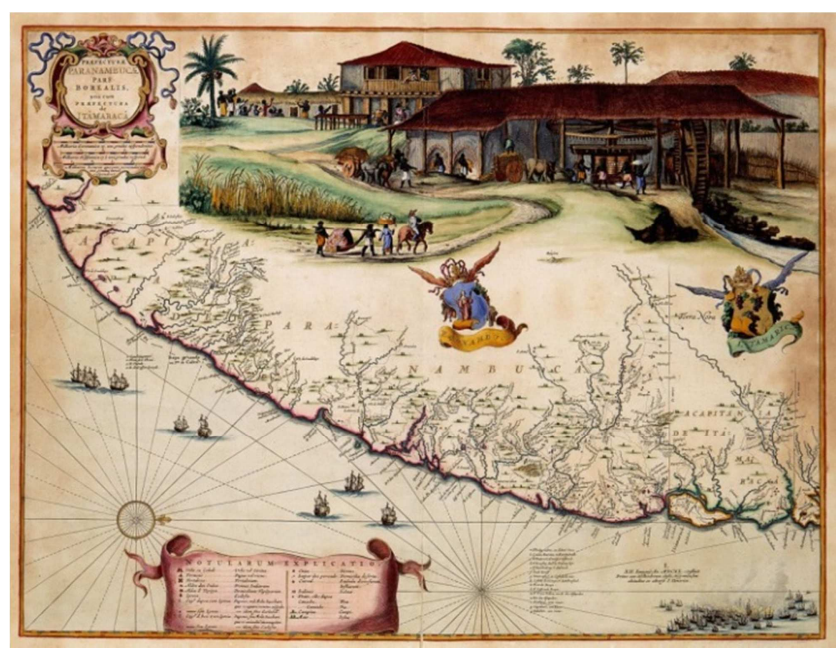

Figure 1. George Markgraaf. Coast of Dutch Brazil, 1630's decade. ${ }^{4}$

Discrimination is more than evident in article number ten of Zur Israel of Recife's statute, which admitted the entry of all Jews residing in Brazil, as well as those who willed to reside in it, as long as they belonged to the Nation. "Our nation" - this is the expression of the statute. Germans and Polish, albeit Jews, were excluded. Blacks were also excluded, as the statute prohibited the circumcision of slaves, even if the masters freed them. The problem did not lie in slave condition, but in black color or in the African origin, and also applied to mulattoes.

In addition to prohibiting the circumcision of blacks, the statute prohibited the circumcision of the so called "strangers", according to the exact words of the Recife Council's law. Who were the strangers? They were not the Ashkenazi Jews, in this case because there were a just few in the Dutch Brazil, unlike in Holland where they were a lot. Besides, the Ashkenazi were circumcised, according the traditional Jew law, eight days after born. The Ashkenazim did not need Sephardic permission or aid to circumcise their newborns, while the Sephardic, at least in Holland, who

4 - Between 1630 and 1654 a large part of Brazil was occupied by the Dutch. In this period the area was surveyed and mapped by the cartographers Cornelius Goliath (deceased 1667/1668) and George Marcgraaf (1610-1644). The results were compiled in a decorative wall map in 1643. Joan Blaeu (1598-1673) used the wall map as his source for this map in 1662 . This work is in the public domain in its country of origin and other countries and areas where the copyright term is the author's life plus 100 years or fewer. Original size of the picture: $5,500 \times$ 4,309 pixels. Available in: https://commons.wikimedia.org/wiki/File:Atlas_Van_der_HagenKW1049B13 095-

PRAEFECTURAE_PARANAMBUCAE_PARS_BOREALIS, una_cum_PRAEF ECTURA_de_ITAMARACA.jpeg always asked the Ashkenazi help (of the German or Polish mohel, in Hebrew) to circumcise the New Jews, often adults or young men, not newborns, in the first decades of the seventeenth.

In fact, the statute did not spell out who the strangers were, but it probably referred to the Old Catholic and the Calvinist Dutch, many eager to marry Jews for many reasons, included the financial. Zur Israel insisted on keeping its distance from the goim (Gentiles), seeming to feel more threatened in Pernambuco than in the Netherlands, in its ideal of purity, realizing that Brazil was a land marked by several mixing culture, religious and race.

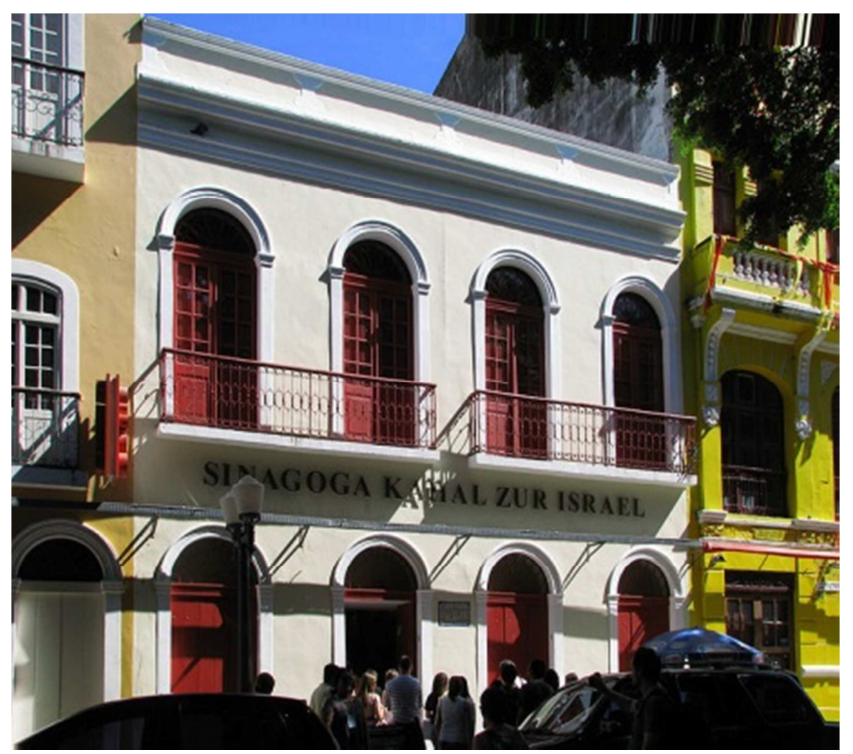

Figure 2. Kahal Kadosh Zur Israel facade nowadays. ${ }^{5}$

Just as it excluded "strange men," Zur Israel congregation excluded "strange women," forbidding them to be taken to Tevilah, that is, the ritual bath linked to conversion to Judaism. The Recife synagogue had its mikveh, a kind of container for the purify bath, for many New Christian women went through this rite when marring with New Jews came from Holland. But Zur Israel avoided using it to baptize Catholic women who wanted to marry the Jews in Dutch Brazil. The Recife congregation assumed a position clearly opposed to mixed unions, attached to a radical endogamy. Paradoxically, while the Talmud Torah in Amsterdam encouraged the conversion of New Christian women, including them who lived in "idolatry lands", like Portugal or Spain, the Zur Israel congregation of Recife used to consider these women more Catholics than Jewish in potential, mainly

5 - Located on Jew Street (Jodenstraat, in Dutch), where slave auctions from Angola and Guinea were also held in the 1640s. The building served several purposes from the eighteenth century and ended up buried in the 19th. In the 1960s, the historian Gonsalves de Mello discovered the temple ruins by researching the Santa Casa de Misericórdia do Recife plant. It was restored over decades and reopened to the public as a museum on October 21, 2001. This file is licensed under the Creative Commons Atributtion-Share Alike 3.0 Unported license. Original size of the photo-file: $2,748 \times 2,205$ pixels. Available in: https://commons.wikimedia.org/wiki/File:Sinagoga_Kahal_zur_Israel,_Fachada.J PG 
the women born from marriages between father Catholic and mother New Christian or vice versa [25].

Other articles of the Zur Israel statute confirm the obsession with keeping the community away from the goim, as if such coexistence threatened the integrity of the group. It is astonish to observe that the Portuguese of Jewish origin coming from Amsterdam to Pernambuco did their utmost to isolate themselves socially from the Catholics, especially since, in the business world, Jews, Catholics and Calvinists shared daily life much more than in Holland. The cause for this contrast perhaps lies in the fact that Portuguese Jews, especially because New Jews, were very fragile in their Jewish identity. In the Netherlands, Catholics, in particular, were an almost clandestine minority, but in Dutch Brazil they were far majoritarian in the free population. This was a strong problem for the New Jews in Dutch Brazil, because they were, in several degrees, men and women culturally ambivalent. The young New Christians, yes, could be more attached to their ancestral religious law. The law of their grandfathers obliged to Catholic conversion in the distant past. But men around thirty or forty years old had enormous troubles to learn the Judaism, to know it. The Catholic heritage was very heavy.

Several individual cases recorded in the inquisitorial processes $^{6}$ [23] allow to affirm that the New Jews, those of Sephardic origin, whether in Holland or in Dutch Brazil, lived a drama of conscience, an identity dilemma, a doubt about which law could guarantee the spiritual salvation of each one, as Schwartz's book show us [18] It would be enough to mention this dilemma for spiritual salvation to confirm the ambivalent conscience of the New Jews, lost among the Catholic experience, while converted; the Jewish memory inherited from parents and grandparents; and the expectation of returning to an unknown Judaism. This was certainly not a dilemma for the Ashkenazi, who knew no any Christian experience, and were more concerned with living God's Law in earthly life than seeking eternal life after death.

In any case, the leaders of Zur Israel in Recife have always been reticent in their relations with others, whether Catholic, Calvinist, or even New Christian from Brazil. They tried to create a kind of a inner cordon, a symbolic wall to separate the Jewish world from the Christian world. In the other hand, they banned criticism against Catholics and Calvinists in religious matters for the "losses and harms" that could cause to the whole community. In other words, they recommended that Jews, Old or New, should avoid divulge or insist on their own belief that the Messiah had not yet arrived.

\section{Conclusion}

In conclusion, I would say that between Amsterdam and Recife, as before - in Italy, Morocco, or the Ottoman Empire

6 - All of them are archived at the Instituto Nacional da Torre do Tombo, Lisbon, Portugal. The respective microfilms' numbers of the Inquisition of Lisbon codex, for the researchers interested in this subject, are: 3637, 4476, 4889, 4895, 4896, $4902,6964,7276,11562$.
- the Sephardic rehabilitated the concept of Men of the Nation. They rehabilitated him in search of an aggregative identity, underlining the strength of kin, ladino language, customs, ancestral beliefs and, above all, the Iberian origins of the group. This was a choice driven by the circumstances of the persecution, that resulted in a revival of Sephardic culture in several parts of the world beyond the Iberian Peninsula, but involved, at the same time, strong identity dilemmas.

The Nation in focus was Jewish and Iberian and from this were resulted various exclusions. In sociability terms, exclusion of Christians from any religious confessions, even the Sephardic who prevailed in Catholicism, mainly in the synagogues; exclusion of mestizos born from mixed unions caused by the territorial mobility of Jews in the Portuguese empire and beyond, specially the mulattoes; exclusion of the traditional Jews themselves, German or Polish, who had never experienced voluntary or forced conversions; exclusion of the New Christians who refused the circumcision or they who descendent from mixed marriages, where one of the parents was Catholic.

The Sephardic community in the European or colonial diaspora, by adopting the concept of Men of the Nation as an identity model, constructed a concept of heresy parallel to that of Iberian Catholicism, attributing to Jewish descendants with other groups an impure origin suspicious to provoke idolatry's relapse, that means, Catholic. The Sephardic New Jews never would accept any doubt an absolute faith, among those trying to return to Judaism: the faith in a true, unique, invisible, indivisible and omnipresent God. But this religious criteria joined itself with serious racial prejudices, as we noted, against the Ashkenazim and the colored people.

The concept of Nation developed in the West would also be aggregative and excluding, at the same time, in the passage from the eighteenth to the nineteenth century. But their bases would be different: secularized, based on a national language and identity, on the ideas of citizenship and sovereign territoriality. The expression Men of the Nation, by this turn, anchored in the Jewish religion and the ethnic origin of its followers, does not, therefore, offer a conceptual antecedent of this historical process. It belongs to the domain of archaisms and traditions, between familial and cultural inbreeding and the notion of an Iberian homeland, Sepharad. Not only a Portuguese or Spanish homeland, but an Iberian homeland, from which, paradoxically, the Men of the Hebrew Nation had been excluded, as assumed Jews, or had been persecuted, if clandestine judaizantes ${ }^{7}$. At last, an idea of homeland that overlooked the historical conflicts between the realms Castilian and Portuguese.

For all these reasons, the Men of the Nation, as group, excluded the mulattoes generated by colonial miscegenation everywhere. Discriminated also European Jews who ignoring the Portuguese or Castilian language; those who, although

\footnotetext{
7 - Judaizantes is an expression that reffered, in that time, to the New Christians, who lived in Iberian World and, though baptized Christians, remained secretly in Judaism.
} 
Jewish by birth, did not pray for the Ferrara Bible. As if Moses was Castilian or Portuguese. As if Moses' native language was the Ladino.

\section{References}

[1] ALMEIDA, M. Regina Celestino. Metamorfoses indígenas: identidade e cultura nas aldeias coloniais do Rio de Janeiro. $2^{\text {a }}$ edição. Rio de Janeiro: FGV, 2013.

[2] ASSIS, Ângelo. Macabeias coloniais: criptojudaísmo feminino na Bahia. São Paulo: Alameda, 2012.

[3] BLUTEAU, Rafael. Vocabulário Português e Latino. Lisboa: Oficina de Pascoal da Silva, 1721.

[4] BODIAN, Mirian. Hebrews of the Portuguese Nation. Conversos and community in early Modern Amsterdam. Indianapolis: Indiana University Press, 1999.

[5] BOER, Harm den. La literatura sefardí de Amsterdam. Alcalá: Universidad de Alcalá de Henares, 1995.

[6] BRAUDEL, Fernand. O Mediterrâneo e o mundo mediterrânico na época de Filipe II. Lisboa: Martins Fontes, 1983.

[7] CARNEIRO, Maria L. Tucci. Preconceito racial no Brasil Colônia. São Paulo: Brasiliense, 1983.

[8] GORENSTEIN, Lina. A Inquisição contra as mulheres. São Paulo: Humanitas, 2005.

[9] HASSAN, Iacob (org). Introducción a la Biblia de Ferrara. Madrid: Ediciones Siruela, 1994.

[10] HERCULANO, Alexandre. História das origens e do estabelecimento da Inquisição em Portugal. Lisboa: Presença, 1979, 3 vols.

[11] ISRAEL, Jonathan. The 'Marrani' in Italy, Greek lands and the Ottoman Near East (1540-1580). In: Diasporas within a Diaspora. Leiden-Boston-Köln: Brill, 2002.

[12] LIPINER, Elias. Terror e linguagem: dicionário da Santa Inquisição. Lisboa: Círculo de Leitores, 1999.
[13] NAHON, Gerard. "Exception française et réponse au modele ibérique: Marie de Médicis et la 'Déclaration qui expulse les juifs du Royaume de France' du 23 avril 1615”. In: Daniele Iancou-Agou (org.). L'expulsion des juifs de Provence et de l'Europe mediterranéee. Leuven: Peeters, 2005.

[14] NETANYAHU, Benzion. Motivos o pretextos? La razón de la Inquisición. In: ALCALÁ, A. (org.) Inquisición Española y mentalidad inquisitorial. Barcelona: Ariel, 1984.

[15] KAPLAN, Yosef. Judíos Nuevos en Amsterdam. Barcelona: Gedisa Editorial, 1996.

[16] RITTER, Harry. Dictionary of concepts in history. Connecticut: Greenwood Press, 1986.

[17] SALOMON, Herman P. Os primeiros Portugueses de Amsterdão. Documentos do Arquivo Nacional da Torre do Tombo, 1595-1606. Braga, 1983.

[18] SCHWARTZ, Stuart. Cada um na sua lei: tolerância religiosa e salvação no mundo atlântico ibérico. São Paulo: Companhia das Letras/EDUSC, 2009.

[19] SICROFFT, Albert. Los estatutos de limpieza de sangre. Madrid: Taurus, 1985.

[20] SOARES, Mariza de Carvalho. Devotos da cor: identidade étnica, religiosidade e escravidão. Rio de Janeiro: Civilização Brasileira, 2000.

[21] SWETSCHINSKI, Daniel. Reluctant Cosmopolitans. The Portuguese Jews of seventeenth-century Amsterdam. Oxford: Littman Library of Jewish Civilization, 2000.

[22] VAINFAS, Ronaldo (org.). Confissões da Bahia. São Paulo: Companhia das Letras, 1997.

[23] VAINFAS, Ronaldo. Jerusalém colonial: judeus Portugueses no Brasil holandês. Rio de Janeiro: Civilização Brasileira, 2010 .

[24] WIZNITZER, Arnold (ed). Actas das congregações Zur Israel, em Recife, e Maghen Abraham, em Maurícia, Brasil, 16481653. Anais da Biblioteca nacional do Rio de Janeiro. Rio de Janeiro: Biblioteca Nacional, 1953, volume 74, 1953.

[25] WIZNITZER, Arnold. Os judeus no Brasil Colonial. São Paulo: Pioneira, 1966. 